DOI: $10.31249 / \mathrm{rsm} / 2019.02 .09$

\title{
А.А. Стракевич
}

\author{
"СТАРЫЕ" И «НОВЫЕ" ПРАВЫЕ ПОПУАИСТЫ \\ В ЗАПААНОЙ ЕВРОПЕ \\ (На примере "Альтернативы аля Германии" \\ и "Австрийской партии свобоАы")
}

Аннотация. Автор рассматривает динамику применимости основных характеристик популизма, упоминаемых в литературе (нарушение дихотомии правые / левые; способность преуспеть, используя замалчиваемые темы; востребованность среди экономически слабых групп населения), к описанию старых (Австрийская партия свободы) и новых (Альтернатива для Германии) популистских партий. Установлено, что популистские партии сохраняют правую ориентацию, несмотря на заигрывание с левой повесткой. Вхождение в правящие структуры ослабляет антиэлитарный компонент их программ. На фоне кризиса партий иентра популисть перестают быть маргинальными партиями, включая в свой электорат «среднего» избирателя. В условиях стремительно расширяющейся базы сторонников решение стигматизировать успехи АПС и АдГ представляется контрпродуктивным.

Ключевые слова: популизм; правые партии; Германия; Австрия; «Альтернатива для Германии»; "Австрийская партия свободыл».

Стракевич Анастасия Алексеевн - аспирант,

Санкт-Петербургский государственный университет,

Факультет международных отношений.

E-mail: a-stra.tomsk@yandex.ru

A.A. Strakevich. The «Old» and «New» Right-Wing Populists in Western Europe on the Example of "Alternatives for Germany" and «Austrian Freedom Party»

Abstract. The article explores the applicability of the main academic characteristics of populism (not following the left / right dichotomy) to the description of old (Freedom Party of Austria) and new (Alternative for Germany) populist parties. It was established that the above-mentioned parties still belong to the right side of the political spectrum, in spite of their references to the left agenda. When populist parties join the ruling groups, the anti-elitist component of their programs gets eroded. The crisis around the centrist parties makes populist forces stop being marginal - the latter tend to embrace «average» voters. 
Keywords: populism; right parties; Germany; Austria; "Alternative for Germany»; «Freedom Party of Austria».

Strakevich Anastasia Alekseevna - Postgraduate Student,

Saint Petersburg State University, School of International Relations.

E-mail: a-stra.tomsk@yandex.ru

«Десятилетие назад, когда новые государства обретали независимость, вставал вопрос: сколькие из них станут коммунистическими? Сегодня этот вопрос, имевший прежде такую актуальность, кажется устаревшим. Дело в том, что лидеры новых государств зачастую выбирают популистские идеологии. И это касается не только новых государств» $[16$, p. 1]. Именно с этих слов начинается сборник «Популизм: его значение и национальные характеристики», опубликованный в 1969 г. Г. Ионеску и Э. Геллнером. Как и сегодняшние политические аналитики, исследователи конца 1960-х годов видели в популизме угрозу и силились понять его природу.

Уже в ходе первых дебатов о природе популизма, инициированных Лондонской школой экономики в мае 1967 г., было сформулировано несколько основных подходов к проблеме. Часть исследователей определяла популизм как идеологию или группу идеологий, воспевающих «народ» или апеллирующих к нему, другая - как некий поведенческий паттерн, возникающий на фоне определенных социальных условий. Исследователи, работающие в поле политической психологии, увязывали популизм с растущим страхом антинародного заговора со стороны внешних сил (колониалистов, интернационального капитала, представителей определенных этнических групп и т.п.) [16, p. 3].

В последующие десятилетия формулировки, впервые возникшие при описании левого популизма, перейдут в характеристики партий правого спектра. Так, в духе своих предшественников, сегодняшний теоретик К. Мудде обозначает популизм как идеологию, разделяющую общество на антагонистические группы - «народ» и «коррумпированные элиты» - и требующую превратить политику в выражение общей воли первой из групп [20, p. 543]. Более того, речь заходит о том, что популизм размывает горизонтальные разделы (к примеру, границу между левыми и правыми) [17, p. 12]. Сохраняются и более частные характеристики: современных популистов обвиняют в стремлении «разрубить гордиев узел политики мечом простых решений» [4, p. 624] и нарушении сложившихся в обществе дискурсивных табу [2, с. 215].

Следует отметить, что вопрос о причинах электоральных успехов популистов занимает современных исследователей даже больше вопроса о сущности популизма. По мнению левого теоретика Ш. Муфф, правый популизм усиливается отсутствием реальных политических дебатов: в условиях доминирования «либерального компромисса» все несогласные с доминирующими 
дискурсивными практиками объявляются «неразумными» и вытесняются за рамки политического поля. Именно эти голоса в дальнейшем канализируют популистские партии [19, р. 3-10]. С изменениями современного партийного поля увязывают рост популизма, к примеру Е.А. Волкова и Ю.И. Лаптева, отмечающие снижение идентификации избирателей с определенными партиями и растущую зависимость электоральных предпочтений от позиций партий по отдельным актуальным вопросам [1, с. 39]. Р. Штёсс обращается к социальным корням популизма: основываясь на западногерманском материале, он утверждает, что лица, не принадлежащие к крупным социальным объединениям (профсоюз, церковь и т.п.), более склонны голосовать за правых популистов [29, S.76]. Х.-Г. Бетц углубляется также в экономические характеристики и указывает, что сторонники правых популистов, как правило, имеют доход нижнего и среднего сегмента, более низкий образовательный уровень в сравнении с электоратом центристов [5, p. 421-422].

В рамках настоящей статьи рассматриваются два «лица» правого популизма. В качестве первого «лица» выступает «Австрийская партия свободы», несколько десятков лет присутствующая в австрийской политике; вторым «лицом» выбрана недавно образованная «Альтернатива для Германии». Сближает партии не только географическое положение соответствующих стран, но и заявляемая ими политическая повестка: евроскептицизм, противодействие миграции, возрождение традиционной немецкой идентичности. Между тем одна из них успела побывать в составе правящей коалиции и превратиться в неотъемлемую часть политического ландшафта своей страны, в то время как другая впервые достигла выдающегося результата на выборах лишь в 2017 г. Строго говоря, наша цель состоит не в том, чтобы сравнить АПС и АдГ по всем возможным критериям; некоторые значимые моменты (к примеру, структура партий) и вовсе остаются за скобками. Анализ партий осуществляется нами в рамках трех тезисов, отражающих характеристики, приписываемые исследователями правым популистам:

1) правые популисты выигрывают от сужения поля политических дебатов;

2) популисты не вписываются в традиционную дихотомию «правые / левые»;

3) правых популистов избирают представители определенных социальных слоев.

Наша цель не только проверить применимость данных тезисов к конкретному эмпирическому материалу, но и установить, насколько значима в контексте соответствующих характеристик длительность присутствия партии на политической арене. 


\section{1. Правые попуяисты выигрывают от сужения поля политических Аебатов}

Формальное вступление «Альтернативы для Германии» в политическое поле страны состоялось в 2013 г. и стало, как считается, результатом объединения трех основных сил: евроскептиков (выходцев из промышленных, академических элит; как правило, бывших свободных демократов), христианских консерваторов (вытесненных из ХДС сдвигом политики партии влево под руководством А. Меркель), националистов и иных антисистемных групп [9, S. 161-162, 8, S. 14]. Последние - на фоне развернувшейся в конце 2014 г. активности движения ПЕГИДА (аббревиатура от немецкого «Патриотические европейцы против исламизации Западной Европы») - быстро превращаются в «лицо» АдГ, воспринимаемой преимущественно как антииммиграционная партия. Следует, впрочем, отметить, члены АдГ не выступали единым фронтом в поддержку ПЕГИДА. Либеральное крыло партии и вовсе предлагало дистанцироваться от «расистских» протестов, вылившихся в многотысячные демонстрации в городах Германии [31, S. 39-40].

Во время региональных выборов 2013-2017 гг. АдГ сумела набрать заметный политический вес практически во всех ландтагах ФРГ. Наибольшие значения были достигнуты в восточных землях (24,3\% в Саксонии-Анхальте и 20,8\% в Мекленбурге-Передней Померании), однако прорывы случались и на западе страны (так, Баден - Вюртемберг подарил партии рекордные 15,1\% голосов) [33]. В 2017 г. группа исследователей, действовавшая по заказу федерального правительства, подготовила доклад о причинах восприимчивости жителей восточных земель к праворадикальным идеям. Среди последних были названы более высокая экономическая незащищенность, сравнительно меньший демократический опыт, а также особенности самоидентификации в условиях государства, функционирующего по «чужим» для жителей бывшей ГДР правилам [35]. Подобные выводы озвучивались в академической среде и ранее - при этом подчеркивалось, что доля иммигрантов в регионе не коррелирует напрямую с секьюритизацией иммиграции [28, S. 178-179].

Осенью 2017 г. «Альтернатива для Германии» добилась впечатляющего электорального успеха на федеральном уровне, став третьей политической силой в стране. Достигнутый результат обернулся серьезными разногласиями как для собственно партийных структур (выход из партии Ф. Петри, раскол и основание «Синего поворота»), так и для политического ландшафта Германии в целом. Основные партии фактически отказались от коалиционного сотрудничества с АдГ, как следствие, формирование правительства затянулось на многие месяцы. Подобная реакция политического поля во многом лишь подтверждает рассматриваемый в этом разделе тезис. Так, АдГ сумела не только нормализовать специфический характер восточногерманской иден- 
тичности на региональном уровне, но и открыто апеллировать к теме иммиграции, обсуждаемой на федеральном уровне лишь в обтекаемых терминах.

В отличие от «Альтернативы для Германии», «Австрийская партия свободы» присутствует в соответствующем политическом пространстве с середины 1950-х годов. Партия сознательно создавалась в качестве альтернативы «Социалистической партии Австрии» и «Австрийской народной партии». Именно в рамках АПС, подчеркивавшей, к примеру, принадлежность австрийцев к германскому культурному пространству, бывшие функционеры национал-социалистического режима сумели вернуться в политику [13, S. 64]. По мнению М. Вилльямс, АПС помогла проработать проблему национальной идентификации австрийцев, будто зависшую в воздухе после окончания Второй мировой войны, когда союзники по антигитлеровской коалиции навязали австрийцам роль коллективных жертв гитлеровской политики. Кроме того, в последующие годы партия сумела стать рупором коллективного недовольства внутренней политикой двух основных партий (в том числе сложившимися коррупционными схемами) [36, p. 154-155].

В 2000-е годы одной из центральных тем для АПС становится борьба с исламизацией. В 2006 г. партия инициирует не слишком удачный сбор подписей против приема Турции в ЕС. Возврат к этой проблематике будет происходить и в последующие годы, в том числе на европейском уровне. В тот же период активизируется критика иммиграции; иммигранты объявляются одной из основных угроз государству всеобщего благоденствия [18, p. 188-191]. Наконец, усиливается антиевропейская риторика, призывающая, как и в случае с внутренними делами, вернуть голос условному «европейскому гражданину». Подходящим инструментом решения этой проблемы «свободным» виделись национальные референдумы по всем значимым интеграционным вопросам [21].

Успех АПС на президентских выборах 2016 г. (тогда кандидат от крайне правых Н. Хофер получил $35,1 \%$ голосов в первом туре, в то время как его главный конкурент, представлявший «Зелёных» А. Ван дер Беллен, завоевал лишь 21,3\%) сопровождался комментариями аналитиков, в целом вписывающимися в рассматриваемый тезис. Так, Ф. Плассер и Ф. Зоммер называют в качестве одной из основных причин успеха АПС размывание традиционной партийной лояльности. По их данным, лишь треть австрийских избирателей чувствует связь с определенной партией - ситуация, обусловленная размытостью и синонимичностью их повестки. При этом электоральное ядро оппозиционных партий представляется более консолидированным; кроме того, дополнительные шансы последним дает обращение к беспартийным группам. Наконец, отмечается общая разочарованность избирателей в партиях и политиках как акторах, эффективно решающих общественные проблемы, - ситуация, благоприятствующая расцвету популистских сил $[25$, S. 3-6]. 


\section{2. Популисты не вписываются}

в традиционную Аихотомию "правые / певые"

На протяжении первых десятилетий существования «Австрийской партии свободы» ее принадлежность к крайне правой части политического спектра представлялась исследователям вполне очевидной. В те годы идеология партии формировалась в рамках переосмысления идей национал-социализма: АПС неизменно подчеркивала «немецкость» австрийцев, хотя речь об отказе от австрийской государственности уже не шла [5, p. 667]. В первой половине 1980-х годов происходит поворот АПС в сторону либерализма. Часть партийной элиты стремилась этим превратить АПС в «уважаемую и полностью интегрированную» силу, однако столкнулась с активным противодействием более радикальных соратников [24, S. 26]. В 1983 г. партия впервые оказывается в составе возглавляемой социалистами правящей коалиции, что только обостряет противоречия внутри партии. В результате в 1986 г. руководство АПС переходит в руки Й. Хайдера, вокруг которого в предшествующие годы сплотились «пронемецкие» группы [13, S. 64].

Парадоксальным образом именно главенство Хайдера приводит партию к новой политической идентичности. Исследователи все чаще называют деятельность АПС «постмодернистской политикой», где термин «постмодернизм» ассоциируется с фрагментарностью программ, размытостью идеологических границ и перформативностью партийных практик [26, p. 6-8]. Действительно, риторика АПС была и остается мозаичной по своему характеру и характеризуется высокой изменчивостью. В одни периоды партия стремилась дистанцироваться от прямых ассоциаций с национал-социализмом; в другие - ее лидеры восхваляли ветеранов СС [14, p. 15] и расшифровывали «НАЦИ» (нацист) как акроним «новый, привлекательный, целеустремленный, инициативный». Подобные лозунги, очевидно, способствовали удержанию в сфере влияния тех радикальных правых, которые не могли быть приняты в нормальном политическом поле. Иные протестные силы привлекались АПС посредством агрессивной антиэлитарной риторики (правительство СПА и АНП партия именовала «красно-черной пиявкой», евробюрократов - «самопровозглашенными палачами Европы») [26, p. 11-12].

В 1999 г., обогнав АНП на несколько сотен голосов, АПС впервые становится второй политической силой в стране и входит в состав «черно-синего» правительства. По мнению авторитетного австрийского исследователя А. Пелинки, секрет успеха АПС следует искать в ее способности возглавить не только правый, но и левый протест. Так, с одной стороны, их лозунги были направлены против монополизации политической и экономической власти представителями основных партий. С другой стороны, АПС пошли по типично правому пути нормализации неравенства через дискурсивное исключение 
иммигрантов [23, S. 285]. Электоральный успех АПС обернулся жесткой реакцией со стороны Европейского союза: 14 стран ЕС заявили, что не будут поддерживать двусторонних контактов с австрийским правительством в случае вхождения в него АПС. Таким образом, АПС сохранила в глазах объединенной Европы устойчивый имидж «слишком правой» партии [30, S. $456-$ 457].

В 2002 г. АПС столкнулась с чередой внутренних конфликтов. Скандалом обернулся визит в Ирак Й. Хайдера и состоявшаяся там встреча политика c С. Хусейном. Позднее противоречия возникали по вопросам сотрудничества с иными европейскими правыми (проект, который горячо поддерживал Хайдер и не одобряла новая глава партии С. Рисс-Пассер), а также проведения налоговой реформы. Разногласия достигли своего пика во время партийного собрания в Книттельфельде 7 сентября 2002 г. На следующий день несколько крупных политиков АПС во главе с вице-канцлером Рисс-Пассер ушли в отставку.

На последовавших выборах АПС существенно сдала позиции, однако сумела вновь войти в правящую коалицию, сформированную в феврале 2003 г. Впрочем, достигнутое с АНП соглашение не встретило единогласной поддержки в партии, разрывавшейся меж двух альтернатив - стать обычной правительственной партией или вернуться в ряды непримиримой оппозиции. В 2005 г. вновь происходит раскол: несколько крупных фигур АПС во главе с Й. Хайдером покидают партию, чтобы основать «Союз за будущее Австрии». В результате все члены правительства и большинство членов парламента от АПС меняют партийную принадлежность - «синие» автоматически утрачивают статус одной из правящих партий и возвращаются к своему традиционному антиэлитарному курсу [15, S. 241-246].

Анализ опубликованной в 2017 г. программы АПС не оставляет сомнений: несмотря на все попытки заигрывать с нетипичной риторикой, «свободные» остаются правой по своему духу партией. Красной линией через весь документ проходит идея «справедливости», понимаемой в правом, т.е. консолидирующем неравенство, смысле. АПС признает необходимость сохранить социальное государство, гарантировать всеобщий доступ к образованию и доступному жилью, но достижение этих целей требует, по мнению АПС, исключения иммигрантов из доступа к соответствующим «привилегиям». Показательна позиция АПС по женскому вопросу: хотя в целом партия соглашается с необходимостью достичь равенства между мужчинами и женщинами, «свободные» по-прежнему апеллируют к материнской роли женщины как неотъемлемой части ее жизни [12].

Новые популисты в лице «Альтернативы для Германии», напротив, исходно не имели четкой привязки к крайне правой повестке. Как отмечалось ранее, создание АдГ стало результатом слияния нескольких сил. Все они - от 132 
преимущественно ориентированных на средний класс евроскептиков и консервативных христианских демократов до радикальных националистических сил - так или иначе принадлежали к правой части политического спектра в том смысле, что апеллировали к «привилегированным» экономическим / этническим классам и отрицали необходимость уравнительных практик. Тем не менее выбор политической ориентации объединения отнюдь не был решенной задачей. Одним из наиболее острых вопросов долгое время остается взаимодействие с правыми радикалами и «группами улицы»- как и члены АПС, представители АдГ то сближались с ними, то демонстративно дистанцировались, стремясь защитить себя от обвинений в расизме и антисемитизме [11].

Важнее, впрочем, другое: по мере включения в избирательную гонку АдГ все чаще обращалась к антиэлитарной риторике, приемлемой как для правых, так и для левых избирателей. Значительная часть программы АдГ посвящена проблеме возвращения утраченного голоса народу: «Альтернатива» предполагает ограничить всевластие партий и ввести референдумы по швейцарскому образцу. Общность «мы» формулируется по этническому признаку: по мнению партии, государство должно поддерживать производство в собственных, а не европейских границах (без чрезмерного вмешательства в экономику), обязать иностранцев интегрироваться в германское культурное пространство, следовать во внешней политике собственным интересам (включающим, среди прочего, сохранение особых отношений с США и прекращение антироссийских санкций). Подход АдГ к школьному образованию предполагает сохранение дифференцированного обучения («Успеваемость, а не инклюзия!») и в целом согласуется с позицией австрийской АПС. В разделе, посвященном экономике, АдГ неожиданно выступает за сохранение минимальной заработной платы, поскольку та «усилит относительно слабую позицию лиц, имеющих низкий доход, перед лицом работодателей» [34, S. 52]. Здесь следует заметить, что в программе отколовшегося от АдГ после выборов «Синего поворота» законодательно закрепленная минимальная заработная плата объявляется следствием «ошибочной социальной политики»; в качестве альтернативы предлагается введение «базового дохода» [3].

Позволяет ли подобная риторика отказаться от наименования «правая» при упоминании АдГ? На наш взгляд, подобное решение нерационально, поскольку исключает из фокуса тот факт, что АдГ претендует на право занять в политическом поле место, освободившееся в результате «полевения» традиционной правой партии ХДС. Впрочем, всякие попытки назвать АдГ еще одной крайне правой партией (исключая популистскую составляющую) также не отражают всей полноты картины. На последних федеральных выборах АдГ смогла привлечь чуть менее 1 млн избирателей, голосовавших прежде за левые партии (СДПГ и «Левые») [7]. Подобный результат нельзя объяснить 
через упоминание минимальных зарплат (тему, успешно представляемую и в левом поле). На наш взгляд - и здесь мы вновь возвращаемся к первому тезису - успех АдГ является результатом игнорирования традиционными элитами назревших в обществе дебатов.

\section{3. Правых попуяистов избирают представитеки определенных социальных слоев}

Во время первого серьезного успеха 1999 г. портрет среднего избирателя АПС в целом соответствовал тенденциям, описанным в литературе. Так, указывает А. Пелинка, за АПС чаще всего голосовали молодые мужчинырабочие, не имеющие высшего образования и религиозной подготовки, не состоящие в профсоюзной организации. Впрочем, мобилизующим моментом в этот период становится не религия и не классовая принадлежность, а модернизация. По мнению А. Пелинки, АПС успешно апеллировала к страхам тех, кто рисковал проиграть от внедрения новых технологий [23, S. 9-10]. Анализ избирательных потоков показывает, что большинство электората, сменившего свои предпочтения в 1999 г. (176 тыс. человек), пришло к АПС от социал-демократов. Еще 138 тыс. человек, голосовавших за АПС, поддерживали ранее умеренную Народную партию [21].

Рассматривая исход выборов 2016 г., исследователи преимущественно указывали на раздраженность избирателей нынешним ходом политического процесса в качестве мотива, руководившего действиями избирателей. Действительно, общий спад доверия к политике представляется наиболее вероятной причиной отказа от поддержки основных партий. Обращаясь к результатам второго тура, нельзя не отметить социально-экономический разлом, разделяющий сторонников Н. Хофера (АПС) и А. Ван дер Беллена («Зелёные»). Электорат Ван дер Беллена имеет заметно более высокий уровень образования; среди электората Хофера сравнительно больше рабочих и меньше госслужащих (в случае с пенсионерами и предпринимателями разрыв практически отсутствует). Наконец - и этот признак исследователи называют базовым - сторонники Хофера уверены, что их качество жизни в будущем будет ухудшаться, тогда как сторонники Ван дер Беллена проявляют в этом отношении оптимизм [32, S. 5-7].

Портрет среднего избирателя АдГ в 2017 г., напротив, заметно отличается от набора характеристик, отличавших прежний электорат немецких правых популистов (Немецкого народного союза, Национал-демократической партии Германии, Партии Шилля, Республиканской партии). Так, среди избирателей правых по-прежнему преобладают мужчины, однако речь не идет о явно очерченной группе, слабой в социально-экономическом смысле. Тенденции, связанные с образованием и уровнем дохода сторонников АдГ, 
в целом типичны для избирателей основных партий (за исключением «Зелёных» и «Левых») [27]. Таким образом, в гипотетической ситуации австрийского сценария - при прямом противостоянии АдГ и «Зелёных» - социальноэкономический разрыв показался бы столь же значительным, однако в условиях реально реализовавшегося сценария акцент сместился в сторону мнений. Вполне ожидаемо, избиратели АдГ сильнее иных избирателей секьюритизируют иммиграцию и критикуют интеграционные процессы в Европе.

Несмотря на общую «нормализацию» характеристик избирателя АдГ на федеральном уровне, сохранились региональные диспропорции, выявленные на предшествовавших выборах в ландтаги. Ни в одной из западных земель АдГ не сумела перейти отметку в $15 \%$, тогда как в восточных землях ее показатели, напротив, не опускались ниже этой границы. Как и в случае с региональными выборами, корреляция между численностью иммигрантов в федеральной земле и симпатиями к АдГ не абсолютна $[6, \mathrm{~S} .16]$; сравнение данных на местном уровне (в том чисде с учетом данных о безработных мигрантах) также не позволяет сделать однозначных выводов [37]. Единственной тенденцией, практически без исключений наблюдаемой на всей территории ФРГ, является зависимость симпатий к АдГ от уровня урбанизации: жители крупных городских центров, как правило, реже голосуют за правых популистов. Объяснение этой тенденции требует анализа дополнительных данных; может основываться как на реально существующих экономических проблемах, так и на особенностях восприятия - к примеру, присущей жителям сельской местности более низкой мобильности.

$$
* \quad * \quad *
$$

Развитие «Австрийской партии свободы» и «Альтернативы для Германии» следовало по совершенно разным сценариям. Одна из них была создана оппозиционными силами в качестве противовеса игнорирующему проблемы центру; другая - учреждена с согласия правящих сил как необходимый системе противовес. Парадоксально, но именно во втором случае противовес долгое время оставался невостребованным со стороны массового избирателя и добился успеха лишь в момент, когда электорат утратил доверие к партиям центра. Успех к АдГ пришел гораздо быстрее, поскольку ее появление само по себе сопровождалось кризисной ситуацией, вызванной общим «полевением» традиционных правых.

Из партий, избираемых экономически слабыми слоями населения, популисты превращаются в партии с широкой электоральной базой. Действительно, ядром их электората остаются наименее защищенные в условиях рыночной экономики группы, однако, по мере нормализации соответствующих партий, к числу их сторонников все чаще примыкают условные «средние» 


\section{РОССИЯ И МИР В ХХІ ВЕКЕ}

граждане. Дальнейшее обсуждение правых популистских партий как маргинальных сил автоматически исключает из диалога широкие слои населения и представляется в связи с этим контрпродуктивным.

Справедливо ли сказать, что популисты не вписываются в дихотомию «правые / левые»? И да, и нет: популисты в лице АПС и АдГ одновременно заигрывают с левой и правой повесткой, делают упор на антиэлитарные лозунги, стремясь максимизировать электоральную поддержку. Подобный сценарий хорош для партии одних выборов, однако закрепление в политическом поле требует стационарности базовых положений. В этом смысле для прогнозирования развития АдГ полезно вспомнить ситуацию, произошедшую с АПС в 2005 г., когда члены, настаивавшие на сохранении популистского компонента, автоматически оказались за пределами правящей коалиции.

\section{Библиография}

1. Волкова Е.А., Лаптева Ю.И. Правый популизм и перспективы выборов в Европейский парламент 2014 года // Вестник Воронежского государственного университета. Серия: История, политология, социология. 2014. № 2. С. 38-41.

2. Ланко Д.А. Популизм и политическое участие: уличные беспорядки в странах Балтийского региона в 2007-2009 гг. // Политическая экспертиза: ПолитЭкс. 2009. Т. 5. № 2. C. 209-230.

3. Außen- \& Sicherhertspolitik. Programm // Blaue Wende. URL: https://www.blauewende.de/ programmatik/ (Дата обращения: 5.10.2018.)

4. Bergsdorf H. Rhetorik des Populismus am Beispiel rechtsextremer und rechtspopulistischer Parteien wie der «Republikaner», der FPÖ und des «Front National» // Zeitschrift für Parlamentsfragen. 2000. Vol. 31. N 3. S. 620-626.

5. Betz H.-G. The New Politics of Resentment: Radical Right-Wing Populist Parties in Western Europe // Comparative Politics. 1993. Vol. 25. N 4. P. 413-427.

6. Bevölkerung und Erwerbstätigkeit. Ausländische Bevölkerung - Ergebnisse des Ausländerzentralregisters // Destatis. URL: https://www.destatis.de/GPStatistik/servlets/MCRFileNodeServlet/ DEHeft_derivate_00035266/2010200177004_korr13062018.pdf (Дата обращения: 29.09.2018.)

7. Blickle P. et al. Merkel-Enttäuschte und Nichtwähler machen die AfD stark // Zeit Online. 2017. 24 Sept. URL: https://www.zeit.de/politik/deutschland/2017-09/wahlverhalten-bundestagswahlwahlbeteiligung-waehlerwanderung (Дата обращения: 29.09.2018.)

8. Decker F. «Die Alternative für Deutschland» aus der vergleichenden Sicht der Parteienforschung // Häusler A. (Hrsg.). Die Alternative für Deutschland Programmatik, Entwicklung und politische Verortung. Wiesbaden: Springer Fachmedien, 2016. S. 7-23.

9. Decker F., Neu V. (Hrsg.). Handbuch der deutschen Parteien. Wiesbaden: Springer VS, 2018. $533 \mathrm{~S}$.

10. Endgültige Ergebnisse nach Wahlkreisen. Wahl zum 19. deutschen Bundestag am 24. September 2017 // Der Bundeswahlleiter. URL: https://www.bundeswahlleiter.de/dam/jcr/3f3d42abfaef-4553-bdf8-ac089b7de86a/btw17_heft3.pdf (Дата обращения: 10.11.2018.)

11. Fiedler M. «Wir wollen eine bundesweite CSU sein»// Der Tagesspiegel. 2017. 11 Nov. URL: https://www.tagesspiegel.de/politik/frauke-petry-im-interview-wir-wollen-eine-bundesweitecsu-sein/20569778.html (Дата обращения: 10.11.2018.) 
12. Freiheitliches Wahlprogramm zur Nationalratswahl 2017 // PdfKurs.com. URL: http://www.pdfkurs.com/Download_PDF_10.php?PDF_Kurs=117036\&PDF_Corriges=nationalratsw ahl_2017_wahlprogramm (Дата обращения: 20.09.2018.)

13. Geden O. Diskursstrategien im Rechtspopulismus. Freiheitliche Partei Österreichs und Schweizerische Volkspartei zwischen Opposition und Regierungsbeteiligung. Wiesbaden: VS Verlag für Sozialwissenschaften, 2006. $246 \mathrm{~S}$.

14. Hainsworth P. The Extreme Right in Western Europe. Abingdon: Routledge, 2008. 160 p.

15. Hämmerle W. Die Spaltung der FPÖ: Annus horribilis für das freiheitliche Lager // Österreichisches Jahrbuch für Politik 2005. Politische Akademie der ÖVP, 2006. S. 239-252.

16. Ionescu G., Gellner E. (eds.) Populism: Its Meaning and National Characteristics. NY: Palgrave Macmillan, 1969. 263 p. $258 \mathrm{p}$.

17. Mény Y., Surel Y. Democracies and the Populist Challenge. Palgrave Macmillan UK, 2002.

18. Meret S. The Danish People's Party, the Italian Northern League and the Austrian Freedom Party in a Comparative Perspective: Party Ideology and Electoral Support. Aalborg: Institut for Historie, Internationale Studier og Samfundsforhold, Aalborg Universitet, 2010. 322 p.

19. Mouffe Ch. The Limits of John Rawls' Pluralism // Theoria: A Journal of Social and Political Theory. 2009. Vol. 56. N 118. Democracy, Morality and Punishment. P. 1-14.

20. Mudde C. The Populist Zeitgeist // Government and Opposition. 2004. N 39 (4). S. 541-563.

21. Nationalratswahl 1999. SORA Institute for Social Research and Consulting // SORA. URL: http://www.sora.at/themen/wahlverhalten/wahlanalysen/nrw99.html (Дата обращения: 10.11.2018.)

22. Pelinka A. Die FPÖ im internationalen Vergleich. Zwischen Rechtspopulismus, Deutschnationalismus und Österreich-Patriotismus // Conflict \& communication online. 2002. Vol. 1. N 1. S. 1-12.

23. Pelinka A. Die FPÖ in der vergleichenden Parteienforschung: zur typologischen Einordnung der Freiheitlichen Partei Österreichs // Österreichische Zeitschrift für Politikwissenschaft. 2002. N 31 (3). S. 281-290.

24. Pelinka A. Die kleine Koalition SPÖ-FPÖ 1983-1986. Wien: Böhlau, 1993. 129 S.

25. Plasser F., Sommer F. Bundespräsidentenwahlen 2016: Politische Einstellungen und Motive der Wähler, regionale Trends und Wählerströme // Österreichisches Jahrbuch für Politik 2016. Politische Akademie der ÖVP, 2017. S. 3-35.

26. Preglau M. Umbruch der politischen Kultur in Österreich: von der schwarz-blau / orange Wende 2000 über das rot-schwarze Interregnum 2006-2017 zu Schwarz / Türkis-Blau 2.0. Max Preglau's Regierungs-Watch // 350 Jahre Universität Innsbruck. 2019. 8 Feb. URL: https://www.uibk. ac.at/soziologie/team/max-preglau/regierungsbeobachtung/info_fpoe_preglau_max.pdf (Дата обращения: 8.02.2019.)

27. Steffen T. Nicht nur die kleinen Leute // Zeit online. 2017. 23 Aug. URL: https://www. zeit.de/politik/deutschland/2017-08/afd-waehler-terrorbekaempfung-integration (Дата обращения: 10.11.2018.)

28. Steglich H. Rechtsaußenparteien in Deutschland: Bedingungen ihres Erfolges und Scheiterns. Göttingen: Vandenhoek \& Ruprecht. 2011. 463 S.

29. Stöss R. Rechtsextremismus im Wandel. Bonn: Bonner Universitäts Buchdruckerei, 2010. $239 \mathrm{~S}$.

30. Van der Bellen A. Die Torheit der Regierenden: Die EU-Sanktionen und ihr Ende // Österreichisches Jahrbuch für Politik 2000. Politische Akademie der ÖVP, 2001. S. 455-472.

31. Vorländer H., Herold M., Schäller S. PEGIDA. Entwicklung, Zusammensetzung und Deutung einer Empörungsbewegung. Springer Fachmedien Wiesbaden, 2016. 165 S. 


\section{РОССИЯ И МИР В ХХІ ВЕКЕ}

32. Wahlanalyse Stichwahl Bundespräsidentschaft 2016. SORA / ISAim Auftrag des ORF // SORA. URL: http://www.sora.at/fileadmin/downloads/wahlen/2016_BP-Stichwahl_Wahlanalyse.pdf (Дата обращения: 10.11.2018.)

33. Wahlergebnisse. Landesparlamente // Wahlrecht. URL: http://www.wahlrecht.de/ ergebnisse/index.htm (Дата обращения: 10.11.2018.)

34. Wahlprogramm der Alternative für Deutschland für die Wahl zum Deutschen Bundestag am 24. Sept. 2017 // Alternative für Deutschland. URL: https://www.afd.de/wp-content/uploads/ sites/111/2017/06/2017-06-01_AfD-Bundestagswahlprogramm_Onlinefassung.pdf (Дата обращения: 10.11.2018.)

35. Walter F. (Her.). Ursachen und Hintergründe für Rechtsextremismus, Fremdenfeindlichkeit und fremdenfeindlich motivierte Übergriffe in Ostdeutschland sowie die Ballung in einzelnen ostdeutschen Regionen. Göttinger Institut für Demokratieforschung, 2017. 232 S.

36. Williams M.H. The Impact of Radical Right-Wing Parties in West European Democracies. NY: Palgrave Macmillan, 2006. 236 p.

37. Zuwanderungs- und Integrationsstatistik // Staatskanzlei des Landes Nordrhein-Westfalen. 2017. 13 Feb. URL: https://www.land.nrw/de/pressemitteilung/43-millionen-menschen-mit-migrationshintergrund-nrw-fortschritte-bei-bildung-und (Дата обращения: 5.10.2018.)

\section{References}

Bergsdorf H. Rhetorik des Populismus am Beispiel rechtsextremer und rechtspopulistischer Parteien wie der «Republikaner», der FPÖ und des «Front National» // Zeitschrift für Parlamentsfragen. 2000. Vol. 31. N 3. S. 620-626.

Betz H.-G. The New Politics of Resentment: Radical Right-Wing Populist Parties in Western Europe // Comparative Politics. 1993. Vol. 25. N 4. P. 413-427.

Bevölkerung und Erwerbstätigkeit. Ausländische Bevölkerung - Ergebnisse des Ausländerzentralregisters // Destatis. URL: https://www.destatis.de/GPStatistik/servlets/MCRFileNodeServlet/ DEHeft_derivate_00035266/2010200177004_korr13062018.pdf (Data obrashhenija: 29.09.2018.)

Blickle P. et al. Merkel-Enttäuschte und Nichtwähler machen die AfD stark // Zeit Online. 2017. 24 Sept. URL: https://www.zeit.de/politik/deutschland/2017-09/wahlverhalten-bundestagswahlwahlbeteiligung-waehlerwanderung (Data obrashhenija: 29.09.2018.)

Decker F. «Die Alternative für Deutschland» aus der vergleichenden Sicht der Parteienforschung // Häusler A. (Hrsg.). Die Alternative für Deutschland Programmatik, Entwicklung und politische Verortung. Wiesbaden: Springer Fachmedien, 2016. S. 7-23.

Decker F., Neu V. (Hrsg.). Handbuch der deutschen Parteien. Wiesbaden: Springer VS, 2018. $533 \mathrm{~S}$.

Endgültige Ergebnisse nach Wahlkreisen. Wahl zum 19. deutschen Bundestag am 24. September 2017 // Der Bundeswahlleiter. URL: https://www.bundeswahlleiter.de/dam/jcr/3f3d42ab-faef-4553bdf8-ac089b7de86a/btw17_heft3.pdf (Data obrashhenija: 10.11.2018.)

Fiedler M. «Wir wollen eine bundesweite CSU sein» // Der Tagesspiegel. 2017. 11 Nov. URL: https://www.tagesspiegel.de/politik/frauke-petry-im-interview-wir-wollen-eine-bundesweite-csu-sein/ 20569778.html (Data obrashhenija: 10.11.2018.)

Freiheitliches Wahlprogramm zur Nationalratswahl 2017 // PdfKurs.com. URL: http://www.pdfkurs.com/Download_PDF_10.php?PDF_Kurs=117036\&PDF_Corriges=nationalratsw ahl_2017_wahlprogramm (Data obrashhenija: 20.09.2018.)

Geden O. Diskursstrategien im Rechtspopulismus. Freiheitliche Partei Österreichs und Schweizerische Volkspartei zwischen Opposition und Regierungsbeteiligung. Wiesbaden: VS Verlag für Sozialwissenschaften, 2006. 246 S. 
Hainsworth P. The Extreme Right in Western Europe. Abingdon: Routledge, 2008. 160 p.

Hämmerle W. Die Spaltung der FPÖ: Annus horribilis für das freiheitliche Lager // Österreichisches Jahrbuch für Politik 2005. Politische Akademie der ÖVP, 2006. S. 239-252.

Ionescu G., Gellner E. (eds.) Populism: Its Meaning and National Characteristics. NY: Palgrave Macmillan, 1969. $263 \mathrm{p}$.

Lanko D.A. Populizm i politicheskoe uchastie: ulichny`e besporyadki v stranax Baltijskogo regiona v 2007-2009 gg. // Politicheskaya e`kspertiza: PolitE`ks. 2009. Vol. 5, N 2. P. 209-230.

Mény Y., Surel Y. Democracies and the Populist Challenge. Palgrave Macmillan UK, 2002. $258 \mathrm{p}$.

Meret S. The Danish People's Party, the Italian Northern League and the Austrian Freedom Party in a Comparative Perspective: Party Ideology and Electoral Support. Aalborg: Institut for Historie, Internationale Studier og Samfundsforhold, Aalborg Universitet, 2010. 322 p.

Mouffe Ch. The Limits of John Rawls' Pluralism // Theoria: A Journal of Social and Political Theory. 2009. Vol. 56. N 118. Democracy, Morality and Punishment. P. 1-14.

Mudde C. The Populist Zeitgeist // Government and Opposition. 2004. N 39 (4). S. 541-563.

Nationalratswahl 1999. SORA Institute for Social Research and Consulting // SORA. URL: http://www.sora.at/themen/wahlverhalten/wahlanalysen/nrw99.html (Data obrashhenija: 10.11.2018.)

Pelinka A. Die FPÖ im internationalen Vergleich. Zwischen Rechtspopulismus, Deutschnationalismus und Österreich-Patriotismus // Conflict \& communication online. 2002. Vol. 1. N 1. S. 1-12. Pelinka A. Die FPÖ in der vergleichenden Parteienforschung: zur typologischen Einordnung der Freiheitlichen Partei Österreichs // Österreichische Zeitschrift für Politikwissenschaft. 2002. N 31 (3). S. 281-290

Pelinka A. Die kleine Koalition SPÖ-FPÖ 1983-1986. Wien: Böhlau, 1993. 129 S.

Plasser F., Sommer F. Bundespräsidentenwahlen 2016: Politische Einstellungen und Motive der Wähler, regionale Trends und Wählerströme // Österreichisches Jahrbuch für Politik 2016. Politische Akademie der ÖVP, 2017. S. 3-35.

Preglau M. Umbruch der politischen Kultur in Österreich: von der schwarz-blau / orange Wende 2000 über das rot-schwarze Interregnum 2006-2017 zu Schwarz / Türkis-Blau 2.0. Max Preglau's Regierungs-Watch // 350 Jahre Universität Innsbruck. 2019. 8 Feb. URL: https://www.uibk.ac.at/ soziologie/team/max-preglau/regierungsbeobachtung/info_fpoe_preglau_max.pdf (Data obrashhenija: 8.02.2019.)

Steffen T. Nicht nur die kleinen Leute // Zeit online. 2017. 23 Aug. URL: https://www.zeit.de/ politik/deutschland/2017-08/afd-waehler-terrorbekaempfung-integration (Data obrashhenija: 10.11.2018.)

Steglich H. Rechtsaußenparteien in Deutschland: Bedingungen ihres Erfolges und Scheiterns. Göttingen: Vandenhoek \& Ruprecht. 2011. 463 S.

Stöss R. Rechtsextremismus im Wandel. Bonn: Bonner Universitäts Buchdruckerei, 2010. $239 \mathrm{~S}$.

Van der Bellen A. Die Torheit der Regierenden: Die EU-Sanktionen und ihr Ende // Österreichisches Jahrbuch für Politik 2000. Politische Akademie der ÖVP, 2001. S. 455-472.

Volkova E.A., Lapteva Yu.I. Pravy`j populizm i perspektivy`vy`borov v Evropejskij parlament 2014 goda // Vestnik Voronezhskogo gosudarstvennogo universiteta. Seriya: istoriya, politologiya, sociologiya. 2014. N 2. P. 38-41.

Vorländer H., Herold M., Schäller S. PEGIDA. Entwicklung, Zusammensetzung und Deutung einer Empörungsbewegung. Springer Fachmedien Wiesbaden, 2016. 165 S.

Wahlanalyse Stichwahl Bundespräsidentschaft 2016. SORA / ISAim Auftrag des ORF // SORA. URL: http://www.sora.at/fileadmin/downloads/wahlen/2016_BP-Stichwahl_Wahlanalyse.pdf (Data obrashhenija: 10.11.2018.) 


\section{РОССИЯ И МИР В ХХІ ВЕКЕ}

Wahlergebnisse. Landesparlamente // Wahlrecht. URL: http://www.wahlrecht.de/ergebnisse/ index.htm (Data obrashhenija: 10.11.2018.)

Wahlprogramm der Alternative für Deutschland für die Wahl zum Deutschen Bundestag am 24. Sept. 2017 // Alternative fur Deutschland. URL: https://www.afd.de/wp-content/uploads/sites/ 111/2017/06/2017-06-01_AfD-Bundestagswahlprogramm_Onlinefassung.pdf (Data obrashhenija: 10.11.2018.)

Walter F. (Her.). Ursachen und Hintergründe für Rechtsextremismus, Fremdenfeindlichkeit und fremdenfeindlich motivierte Übergriffe in Ostdeutschland sowie die Ballung in einzelnen ostdeutschen Regionen. Göttinger Institut für Demokratieforschung, 2017. 232 S.

Williams M.H. The Impact of Radical Right-Wing Parties in West European Democracies. NY: Palgrave Macmillan, 2006. 236 p.

Zuwanderungs- und Integrationsstatistik // Staatskanzlei des Landes Nordrhein-Westfalen. 2017. 13 Feb. URL: https://www.land.nrw/de/pressemitteilung/43-millionen-menschen-mit-migrationshintergrund-nrw-fortschritte-bei-bildung-und (Data obrashhenija: 5.10.2018.) 